\title{
Currarino syndrome in an adult woman
}

\author{
Jeongeun Shin ${ }^{1,2}$, Da Kyung Hong ${ }^{1,3}$, Young Hwa Kim ${ }^{4}$, Kyung Taek Lim ${ }^{1,5}$, Ki Heon Lee ${ }^{1,3}$, Tae Jin Kim ${ }^{6}$, \\ Kyeong A So
}

\begin{abstract}
Department of Obstetrics and Gynecology, ${ }^{1}$ Cheil General Hospital and Women's Healthcare Center, College of Medicine, Dankook University, ${ }^{2}$ Yonsei University College of Medicine, ${ }^{3} \mathrm{CHA}$ Gangnam Medical Center, CHA University; ${ }^{4}$ Department of Radiology, Cheil General Hospital and Women's Healthcare Center, College of Medicine, Dankook University; Department of Obstetrics and Gynecology, ${ }^{5}$ Hallym University Kangdong Sacred Heart Hospital, ${ }^{6}$ Konkuk University School of Medicine, Seoul, Korea
\end{abstract}

Currarino syndrome is a hereditary disease characterized by the triad of sacral agenesis, anorectal malformation, and presacral mass. Most patients are diagnosed in childhood, and this condition rarely manifests in adulthood. In women, gynecological malformations associated with Currarino syndrome have been reported, such as bicornuate uterus, rectovaginal fistula, and septate uterus. We present a rare case of a 29 -year-old woman with a suspected pelvic mass who was diagnosed with Currarino syndrome.

Keywords: Anorectal malformation; Sacral agenesis; Currarino syndrome

\section{Introduction}

Currarino syndrome is a congenital disorder characterized by the clinical triad of anorectal malformations, sacral agenesis, and a presacral mass such as an anterior meningocele [1]. Chronic constipation is the most common symptom of this disorder, secondary to extrinsic compression of the presacral mass or anorectal malformations [1,2]. In most cases, this condition is diagnosed in childhood, and rarely, in adulthood [3]. We report a case of a 29-year-old woman who visited our gynecology department for evaluation of a pelvic mass who was diagnosed with Currarino syndrome. We have additionally reviewed the relevant literature.

\section{Case report}

A 29-year-old woman was referred to our hospital for evaluation of a pelvic mass that was identified during a gynecological examination at a local hospital in October 2017. She had visited the local clinic for a routine gynecological checkup before marriage. She denied any relevant family or medical history; however, she reported a history of chronic constipation since birth. Her menstrual cycle had been regular, i.e., every 30-35 days, since menarche at the age of 18 years. She often had mild dysmenorrhea but no pelvic pain. On speculum examination, the cervix showed a smooth surface but was deviated to the upper right. Her anus was relatively small (measuring approximately $1 \mathrm{~cm}$ in diameter), and the perineum was relatively long at approximately $5 \mathrm{~cm}$.

Ultrasonography revealed a septate uterus with bilaterally normal ovaries. An approximately $10-\mathrm{cm}$ solid calcified mass was observed in the left posterior portion of the uterus. This pelvic mass was suspected to be a subserosal myoma or nongynecological mass. Pelvic magnetic resonance imaging (MRI) was performed to further evaluate the pelvic mass, which was identified as a fecal mass on MRI. The partial septate uterus showed right anterior displacement secondary to a massively distended rectum (Fig. 1A). Rectal and anal sphincter stenoses were observed. A septated cystic mass measuring approximately $4.7 \times 3.3 \times 2.5 \mathrm{~cm}$ in size was observed

Received: 2018.09.27. Revised: 2019.01.03. Accepted: 2019.01.17. Corresponding author: Kyeong A So

Department of Obstetrics and Gynecology, Konkuk University School of Medicine, 120-1, Neungdong-ro, Gwangjin-gu, Seoul 05030, Korea

E-mail: joyfulplace@hanmail.net

https://orcid.org/0000-0002-3566-8436

Articles published in Obstet Gynecol Sci are open-access, distributed under the terms of the Creative Commons Attribution Non-Commercial License (http://creativecommons org/licenses/by-nc/3.0/) which permits unrestricted non-commercial use, distribution, and reproduction in any medium, provided the original work is properly cited.

Copyright (๑ 2019 Korean Society of Obstetrics and Gynecology 


\section{Obstetrics \& Gynecology Science}

Vol. 62, No. 5, 2019

in the right presacral area, and it was continuous with the dilated thecal sac through a right sacral defect, which was consistent with an anterior meningocele (Fig. 1B). The sigmoid colon was dilated to $7-8 \mathrm{~cm}$ in diameter and extended to the anterior aspect of the liver and right subphrenic space (Supplementary Fig. 1A). The right kidney of the patient was small in size $(7 \times 3.4 \times 3 \mathrm{~cm})$, and showed calyceal blunting and dilatation (Supplementary Fig. 1B). The left kidney showed compensatory hypertrophy $(12 \times 7 \times 6 \mathrm{~cm})$. Plain radiography revealed a right-sided sacral bone defect; however, the right $\mathbf{S 1}$ was intact (scimitar sacrum; Fig. 2). Abdominal radiographs showed a massively distended sigmoid colon filled with feces. Sacral dysgenesis was observed below the level of the right $\$ 2$ and around the left $\$ 4$, along with erosive changes.

Physical examination and imaging studies suggested Currarino syndrome characterized by a presacral mass, anorectal malformations, and sacral agenesis. The patient was transferred to a tertiary hospital for further evaluation and treatment.

\section{Discussion}

Currarino syndrome is a rare autosomal dominant hereditary disorder [4]. Since the Currarino triad was first described by Currarino in 1981, approximately 300 cases have been reported [3-5]. However, the exact incidence of this condition is unknown owing to its multiple phenotypes and clinical presentations [5]. Recent studies have reported an association between Currarino syndrome (primarily sacral agenesis) and the HLXB9 gene located on chromosome 7q36 [4]. Reportedly, an HLXB9 gene mutation was identified in approximately $90 \%$ of familial cases and $30 \%$ of sporadic cases [6]. The female-to-male ratio was reported to be $3: 1$ among non-familial and 1:1 among familial cases $[4,7]$. The higher incidence rate in women is attributable to the greater number of hospital visits made by women for gynecological and/ or urological symptoms [4].

Patients usually present with various symptoms, including meningitis, perianal abscess, abdominal distention, bowel obstruction, chronic constipation, and/or urinary tract infection [1-5]. Chronic constipation is the most common symptom [1]. Our patient reported a history of chronic constipation since childhood. Constipation is attributable to anal malformations and compression caused by the presacral mass $[7,8]$. Most patients are diagnosed in childhood; this condition is rarely observed in adults [3]. A previous report described a 30-yearold woman who was diagnosed with Currarino syndrome after gynecological evaluation for recurrent abortion [7]. She
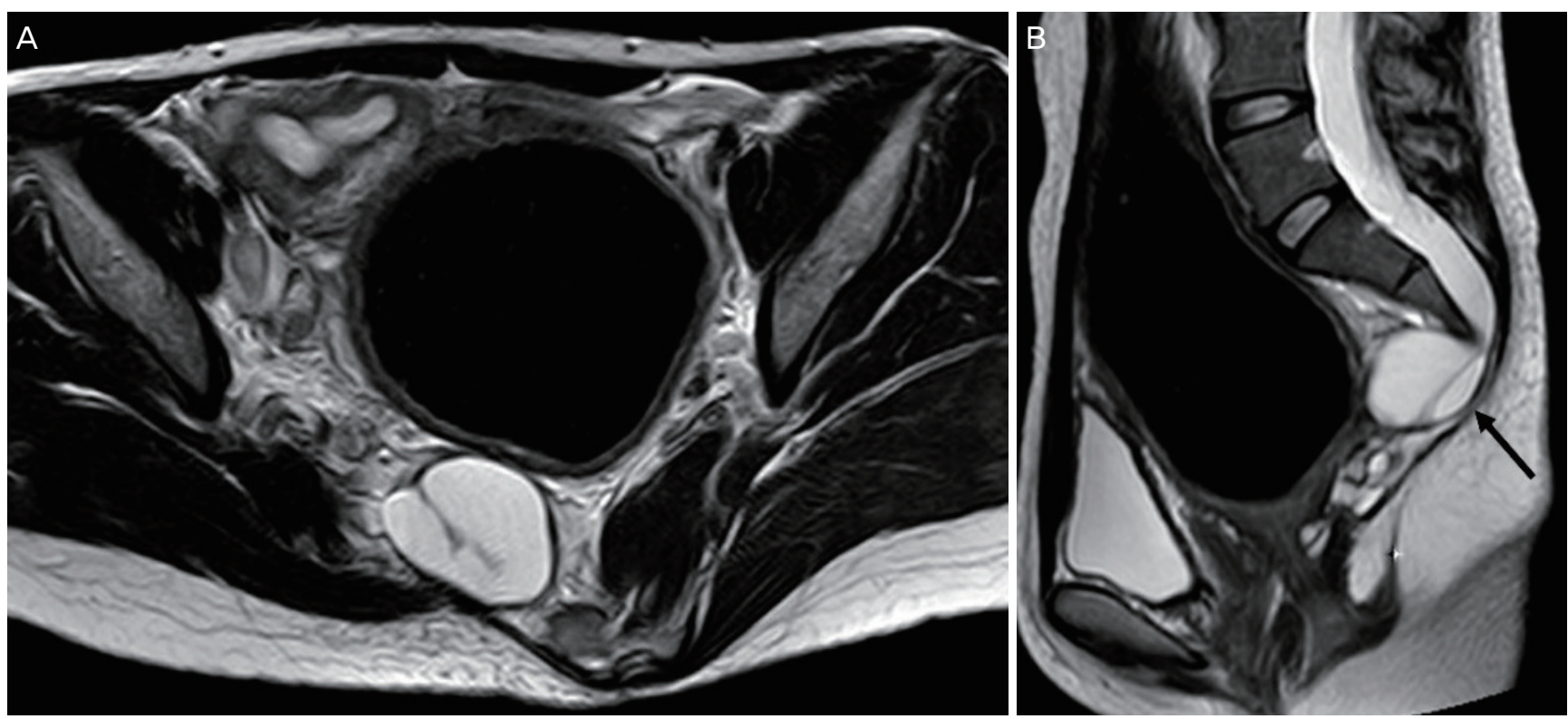

Fig. 1. Pelvic magnetic resonance image shows $(A)$ a partial septate uterus ( $1.7 \mathrm{~cm}$ of the muscular septum) with right anterior displacement secondary to a massively distended rectum. (B) Right-sided anterior sacral meningocele (arrow) is observed. 


\section{Obstetrics \& Gynecology Science}

Jeongeun Shin, et al. Currarino syndrome in an adult woman

reported a several-year history of low back pain and chronic constipation since birth. She had undergone surgery for anal atresia at 6 months of age. Gynecological workup revealed a bicornuate uterus and sacral bone defect. Pelvic MRI revealed an extremely large anterior sacral meningocele, and she was referred to the Department of Neurosurgery. Another case report described a 22-year-old woman with chronic constipation who visited a neurosurgical clinic [2] and was diagnosed with Currarino syndrome on the basis of pelvic radiographs and MRI, which showed partial sacral agenesis, meningocele, and a bicornuate uterus. She reported a history of constipa-

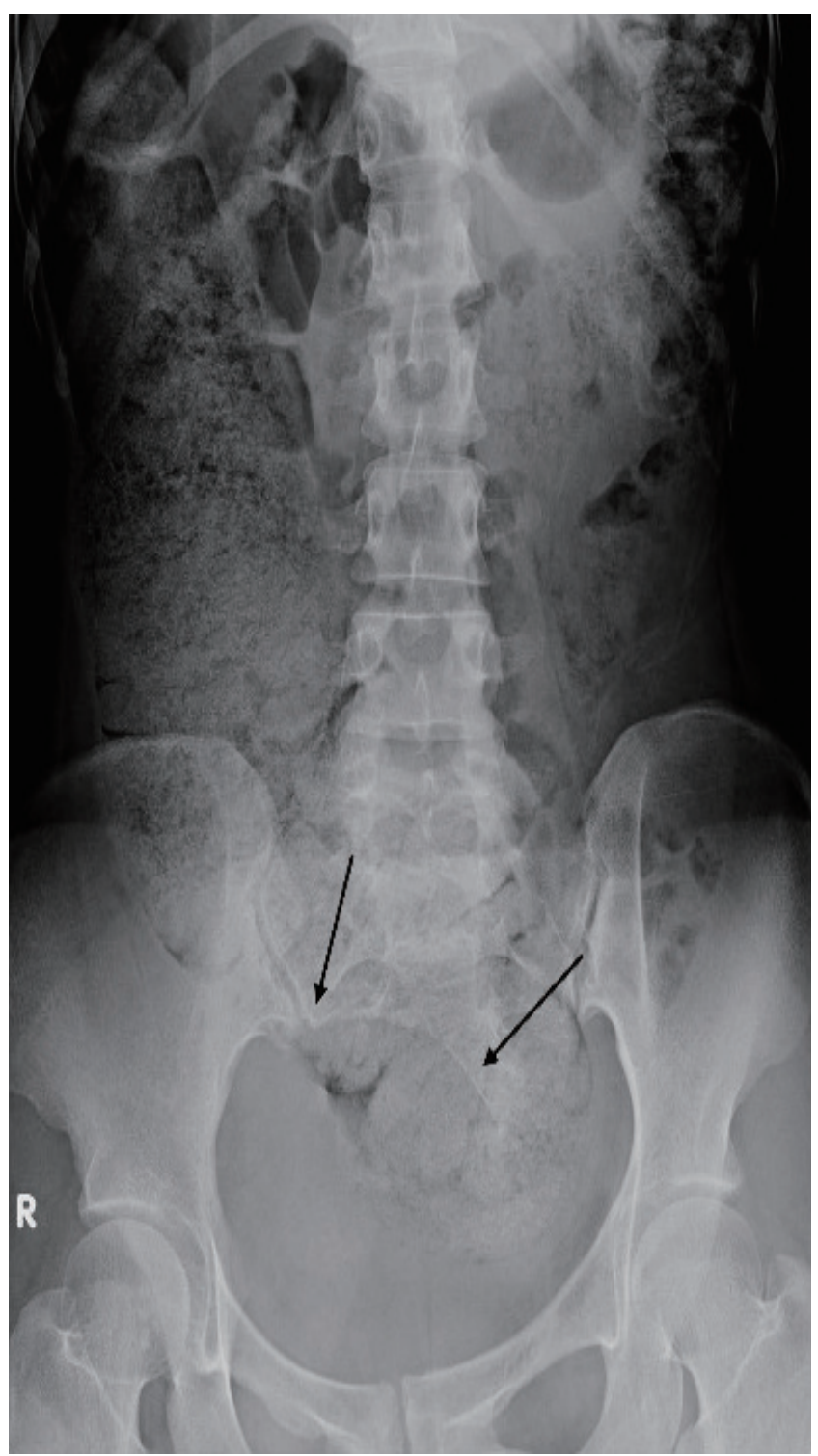

Fig. 2. Abdominal radiograph shows sacral hypogenesis (scimitar sacrum) and a massively distended sigmoid colon filled with feces. tion since birth and had undergone anorectoplasty for congenital anal atresia at 3 years of age. Previous reports have described patients with anal malformations such as anal stenosis, which were diagnosed and treated during childhood [2]. Although not diagnosed as having Currarino syndrome at the time of presentation (in childhood), these patients were diagnosed in adulthood when they presented with other associated symptoms $[2,4,7]$. Therefore, the diagnosis of anal malformations during childhood warrants additional evaluation to exclude Currarino syndrome.

Patients with Currarino syndrome show a highly variable clinical presentation. In women, gynecological malformations, including a bicornuate or septate uterus and a rectovaginal fistula, have been reported in $19 \%$ of cases [4]. These uterine structural abnormalities can cause infertility, recurrent miscarriage, and premature births [7]. Therefore, women diagnosed with Currarino syndrome should undergo gynecological evaluation to identify the structural abnormality.

Physical examination and imaging studies, including radiography, ultrasonography, computed tomography, and MRI, are useful diagnostic tools. Pelvic MRI is useful to distinguish between a presacral mass and the surrounding structures. The presacral mass is primarily an anterior meningocele, although teratomas, hamartomas, and neurogenic cysts, among other such lesions, may occur. In addition, MRI is useful to identify other deformities related to the spinal canal $[1,7]$. The treatment of Currarino syndrome depends on its presentation. Anorectal malformations require an anorectoplasty; however, conservative management could be attempted if symptoms are not severe $[7,8]$. An anterior meningocele requires urgent surgical treatment to avoid the risk of meningitis $[5,7]$. Notably, an enlarging presacral mass may cause acute symptoms such as bowel obstruction secondary to a mass effect and, therefore, requires prompt treatment [3].

In summary, a 29-year-old woman visited our gynecology department with a suspicious pelvic mass. Her anus was relatively small, and she reported a history of chronic constipation since birth. Gynecologists should be aware of the possibility of Currarino syndrome in patients who seek treatment for a presacral mass. Women presenting for a gynecological examination require a thorough examination to rule out Currarino syndrome if their physical examination shows anorectal malformations, presacral mass, or similar suspicious symptoms. 


\section{Obstetrics \& Gynecology Science}

Vol. 62, No. 5, 2019

\section{Conflict of interest}

No potential conflict of interest relevant to this article was reported.

\section{Ethical approval}

The study was approved by the Institutional Review Board of Cheil General Hospital (IRB No. CGH-IRB-2018-18) and performed in accordance with the principles of the Declaration of Helsinki.

\section{Supplementary material}

Supplementary Fig. 1 associated with this article can be found online at https://doi.org/10.5468/ogs.2019.62.5.367.

\section{References}

1. Ilhan H, Tokar B, Atasoy MA, Kulali A. Diagnostic steps and staged operative approach in Currarino's triad: a case report and review of the literature. Childs Nerv Syst 2000;16:522-4.
2. Berghauser Pont LM, Dirven CM, Dammers R. Currarino's triad diagnosed in an adult woman. Eur Spine J 2012;21 Suppl 4:S569-72.

3. Aydoseli A, Akcakaya MO, Aras Y, Dolas I, Yanar H, Sencer $A$. Anterior sacral meningocele in a patient with Currarino syndrome as a cause of ileus. Br J Neurosurg 2013;27:833-5.

4. Lynch SA, Wang Y, Strachan T, Burn J, Lindsay S. Autosomal dominant sacral agenesis: Currarino syndrome. J Med Genet 2000;37:561-6.

5. Shoji M, Nojima N, Yoshikawa A, Fukushima W, Kadoya $\mathrm{N}$, Hirosawa $\mathrm{H}$, et al. Currarino syndrome in an adult presenting with a presacral abscess: a case report. J Med Case Reports 2014;8:77.

6. Kim AY, Yoo SY, Kim JH, Eo H, Jeon TY. Currarino syndrome: variable imaging features in three siblings with HLXB9 gene mutation. Clin Imaging 2013;37:398-402.

7. Işik N, Balak N, Kircelli $A$, Göynümer $G$, Elmaci I. The shrinking of an anterior sacral meningocele in time following transdural ligation of its neck in a case of the Currarino triad. Turk Neurosurg 2008;18:254-8.

8. Emoto S, Kaneko M, Murono K, Sasaki K, Otani K, Nishikawa $T$, et al. Surgical management for a huge presacral teratoma and a meningocele in an adult with Currarino triad: a case report. Surg Case Rep 2018;4:9. 